\title{
Impact of Team Trust on Project Quality and Timeliness in Bayelsa State Civil Service, Nigeria
}

\author{
Omoankhanlen Joseph Akhigbe ${ }^{1 *}$ \\ Emelah Gentle $\mathrm{E}^{2}$ \\ Department of Management ${ }^{1 \& 2}$ \\ University of Port Harcourt, Port Harcourt, Nigeria ${ }^{1 \& 2}$
}

\begin{abstract}
This study examines the extent to which team trust can bring about project quality and project timeliness in Bayelsa state civil service. A total of 14 ministries and parastatals were studied and 131 team members were our respondents. Spearman Rank order correlation was used for testing our stated null hypotheses. From our findings, we realized that both project and project timeliness were significantly influenced by team trust with positive correlation coefficients and p-values less than 0.05 . Therefore, our null hypotheses were rejected. The study further concluded that team members should be supportive to their colleagues. This action will increase benevolence among members and ensures that projects delivered conformed to specification. Secondly, Ethical codes should be developed for team members. This will boost team trust and leads to timely completion of projects and lastly, Teams should be made up of competent individuals. This will help achieve project satisfaction.
\end{abstract}

Keywords: Integrity, Quality, Timeliness, Project, Team, Ministries,

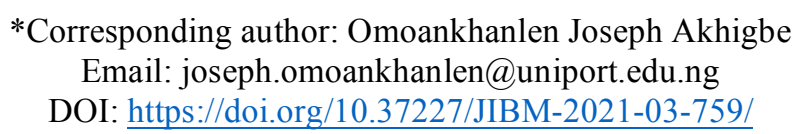

\section{Introduction}

Every project team, whether in the private or public sector, strives to be successful. Moreover, the success of teams is a function of the level of performance in their projects. Thus, project performance is an organisational concept that has come to stay and is currently attracting enormous attention from management scholars and experts. In fact, every project member and leader are concerned about the performance of the team (Bartholomew \& Sule, 2017). Eja and Ramegowda (2020) contended that the success in the executions of projects, is vital in boosting a country's development. Boosting project success is a function of its team members (Rodriguez-Rivero, Ortiz-Marcos, Romero \&Ballesteros-Sanchez, 2020). Modem business organisations and managers are focusing their attention on teams and using teams to deliver quality, timely and satisfying projects, products or services as well as settling organisational problems and resolving customers' complaints. Organisations also involve teams in undertaking complex assignments (Fung \& Siow, 2013). The adoption of teams to resolve complex issues shows that project performance through team is more advantageous than individual performance as the team outputs exceed the totality of 
individual accomplishments (Finnegan, 2002). This gives a justification for the significance of teams in the performance of projects, specifically projects of public utilization.

On the hand, the concept of trust has become popular in public debate and academic research. In high income countries, this interest is associated with concern for the waning of trust in government establishments and among corporate professionals. Also, in developing countries the interest has been prompted by debates around the notion of social capital (Paliszkiewicz, 2011). Trust has been pointed out as a key influencing factor in almost every organisational variable including capital investment, relationship promotion, cross-cultural interaction, learning and several facets of cooperation. Also, it is believed that trust is key for successful operations and effectiveness in organisations (Zand, 1972;Zand, 1997; Lewis \& Weigert, 1985; McAllister 1995; Lane, 1998;Rousseau, Sitkin, Burt \& Camerer, 1998; Nooteboom, 2002).

Moreover, trust is crucial in every area of corporate and social life. It connects friendships (Gibbons, 2004), it helps in successful negotiation among parties (Olekalns \& Smith, 2005), it reduces the cost of transaction in exchanges that involve two different firms (Bharadwaj \& Matsuno, 2006), and amicably resolves international political conflicts (Kelman, 2005). It is also crucial in decisions concerning investment (Lorenz, 1988). Lorenz (1988) posited that the availability of trust gives room for successful asset investments because there is an assumption that parties will not abuse their bargaining power after agreement on the terms.

Trust is a vital component in any positive and productive social process. Feitosa, Grossman, Kramer and Salas (2020) maintained that team trust is vital in enhancing performance. Within organisational setup, trust has been shown to be a vital factor in predicting organizational result including supportive behavior (Zalabak, Ellis \& Winograd,2000), organisational citizenship behaviour (Van Dyne, Vandewalle, Kostova, Latham \& Cummings, 2000), commitment to the organization (Aryee, Budhwar, \& Chen, 2002) and loyalty of employee (Costigan, liter \& Berman, 1998). Building employees' trust is considered necessary for employers. Yet, the way to go in the maintenance of trust from employees in the organisation remains a major concern of employers in the world today (Zhang, Tsui, Song, Chaoping \& Jia, 2008).

Organisations from different sectors are increasingly making effort to increase trust among their teams in anticipation that it will translate to enhanced performance of projects (Reilly \& McGourty, 1998). The increasing efforts by organisations to enhance trust level in organisations provides a strong indication that the result obtained when there is trust is higher compared to those obtained without trust (Reilly \& McGourty, 1998). Scholars and researchers alike as well as project managers agree that a key factor if project objectives are to be accomplished is trust. The advantages of having a trusted team cannot be overemphasized. Some of these benefits include: increased productivity (Campion, Medsker, \& Higgs, 1993); enhanced performance (Tannenbaum et al., 1996), greater employee satisfaction (Cohen, \& Spreitzer, 1995), (Katzenbach \& Smith, 1993) improved customer service and satisfaction (Guzzo, 1995; Reilly \& McGourty, 1998; Sundstrom, 1999) and improved efficiency (Guzzo\& Dickson, 1996).

Till date, several of studies have been conducted on the team trust implications on project performance over a wider scope of groups and other settings (e.g., Langfred, 2007; Lee, Gillespie, Mann \& Wearing, 2010; Braun, Peus, Weisweiler, \& Frey, 2013). Based on these numerous studies, one would expect studies about team trust and performance to have yielded similar results, so as to advise business executives and researchers appropriately. 
Trust has remained one of the most discussed topics in organizational science in the past two decades. This interest is partly explained by the recent developments in the way of thinking and functioning of organisations. For sustainability of organizational effectiveness, there is less reliance by organizations on the rigid bureaucratic structure, instead they now depend on the collaborative structure of teams within and outside the organizations (Taillieu, 1990; Roe, 1992).Costa, Fulmer and Anderson (2017) submitted that "trust in work teams is an exciting area of research that contributes to our understanding about how individuals and teams interact and how teamwork dynamics influence performance and other effectiveness outcomes".

Conceptualizations on team trust, or trust among organisational members have been proposed across several disciplines for many years. Loads of studies on team trust can be found in specialisations such as management, industrial psychology, philosophy, psychology, marketing, ergonomics, sociology, human-computer interaction, and electronic commerce (Alijanpour, Dousti, \& Alijanpour, 2013; Ba§tug, Pala, Kumarta§li, Giinel, \& Duyan, 2016). When one considers these multiple disciplines together, the literature on trust is quite voluminous. Despite the fact that trust has been the subject of multiple studies indifferent disciplines, everyone of these disciplines has produced its own concepts, definitions and findings.

Although most scholars agree that trust engenders various benefits such as team performance, effectiveness and success (e.g., Roe, Zinovieva, Dienes \& Ten Horn, 2000), research on this topic has been hampered by the lack of agreement in defining this concept. In fact, trust has become somewhat mercurial and defies any effort to integrate it as unified concept. Thus, team trust and its management has taken a central position in firm management and is considered strategic to team performance (Zhang, Tsui, Song, Chaoping, \& Jia, 2008).

\section{Stakeholder Theory}

\section{Theoretical Framework}

There has been growing interest in the stakeholders theory since the publication of Freeman Edward in 1984 (Agle, et al, 2008). The result of this is the shift from the focus of stockholders and now the established use of stakeholder in the business world. Stakeholder theory was originated from the study of ethics and management of organizations (Phillips et al., 2003). Stakeholder theory suggests that attention must be paid to all components in order to affect the organizational value (Jensen, 2010).

The stakeholders' theory holds that, corporations and their managers have the duty to give account of their actions not only to their stockholders or financials, but to all individuals or groups in which their operations their direct or indirect impact (Jensen \& Sandstrom, 2011). Furthermore, the stakeholders' theory holds that, project team satisfaction can influence project performance through stakeholders. Project manager together with other project team members are part of stakeholders of the project performance. In project context, stakeholders are people or organizations inclusive project manager, team members, customers, sponsors, performing organizations, general public et al. who are involved in the project that can exert influence over the project or their interests can be affected by the project performance (PMI, 2008).

When the project team members are more satisfied, their stakes increased that will motivate them further to achieve the desire project performance. Naturally every project team member wants to see the team succeed because each of them is a stakeholder of the project deliverables. If the project is not delivered successfully, this will look bad not only to the 
team but also to each of them. Since each (team member) has a stake, they have no choice but to perform their role or portion of work well. But at the same time if the team feels more satisfied, they will produce more or help out each other to deliver the project performance as needed. The stakeholders' theory bridges the vacuum noticed in the agency and stewardship theories. The stakeholder theory recognizes that, organization is a composition of several stakeholders who jealously fight to protect their individual interest (Olori \& Sylva, 2017). However, the agency and stakeholder theories failure is their "inability to highlight the pluralistic composition of a corporation" (Olori \& Sylva, 2017, p.33).

\section{Concept of Team Trust}

Teamwork is paramount in fostering the fortune of all firms (Berber, Slavic \& Aleksic, 2020). Gills (2003) characterizes team trust as the firm's ability, in view of its way of life practices seeing someone properly defenceless, in light of the conviction that another individual is skilful, transparent, concerned, and dependable to shared objectives, standards, and estimations of the relationship. In any case, in this examination team trust is characterized as a firms team recognition on the eagerness of another colleague (trustor) to acknowledge being defenceless against the activities of other colleague or individuals (trustees) with the accept that the associates will play out a specific activity satisfactory to the trustor, regardless of the capacity or powerlessness of the trustor to screen or control the other colleagues. Trust in team is a collective phenomenon and it is a catalyst effectiveness and performance (Imam \& Zaheer, 2021). In any case, as changed as these meanings of trust seem to be, they share some basic components. To begin with, most definitions recognize that trust is identified with singular attributions about others' expectations and thought processes hidden their conduct (Smith and Barclay, 1997). Second, these attributions impact and are affected by general convictions and desires for people about the treatment they will get from others (Mayer, Davis and Schoorman, 1995). Thus, these are firmly connected to the commitment, or the readiness to draw in, practices of trust while collaborating with others (Deutsch, 1962; Kramer, Brewer, and Hanna, 1996). At long last, these attributions and convictions are unforeseen to a specific setting, and will in general be put together with respect to individual data as well as on non-individual (situational) data that either serves to improve or to hinder the advancement of that trust (Morris and Moberg, 1994).

In light of these contemplations, trust could be seen as a mental express that (i) shows itself in the practices towards others, (ii) depends on the desires heaps of these others, (iii) and on the apparent thought processes and expectations in circumstances involving hazard for the association with those others. In this definition trust is seen as a frame of mind held by a person in connection to another individual or gathering of people and it is material to work connections in group settings. Predictable with Mayer et al., (1995) coordinated model of trust, this definition recognizes the mental express, the desires and the practices towards others, which are conceptualized as unmistakable yet related segments of trust. Also, this conceptualization parallels different meanings of trust as a multidimensional or multifaceted build (e.g., Smith and Barclay, 1997).

The previous implies that practices are a significant segment of trust, since they mirror the noteworthiness of the choice about trusting or not (Smith and Barclay, 1997) by empowering people to follow up on their own decisions (Lewis and Weigert, 1985). Additionally, it is through the perception and translation of these practices that people find out about one another's thought processes and expectations, and can make derivations of reliability (Zand, 1972). Thusly, in this examination, trust practices are viewed as segments of trust together with affinity to trust and saw dependability. 


\section{Project Quality}

Over the last few decades, public sector organizations are confronted with proliferating challenges. Pressure from budgets in addition to the continuous request for accountability and couples with the increasing and flexible expectations from the public in the public sector has forced them into finding new ways to provide lasting solutions. Thus, government parastatals are therefore seeking to adopt new processes, techniques and technologies to increase process efficiency, reduce costs, and improve the quality (Boyne, 2004; Stringham, 2004). Project need to be efficaciously organized in order to ensure its quality (Eja \& Ramegowda, 2020).

Private firms have achieved proven successes in increasing quality and minimizing costs by increasing efficiency and processing capacity by implementing best practices in various management techniques. Today, public sector organizations are under pressure to deliver the same or better quality (Poister \& Harris, 2002; O'Toole \& Meier, 2003; Ingraham et al., 2003). Project quality has been described using several terms such as durability, performance specification, serviceability, flexibility, features reliability, conformance and degree by which the product or service meets the customer's expectations. Tellis, Yin, and Niraj (2009), stated that governments invest extensively in project quality, initiatives and innovations to ensure acceptable quality of the projects.

Quality is a very broad concept which has metamorphosed in modem management literature (e.g., Reeves \& Bednar, 1994; Loffler, 2002; Bovaird \& Loffler, 2003). Quite often 'quality' is defined as the conformance to previously established specifications (e.g., Levitt, 1972; Gilmore, 1974; Juran, 1974) or to requirements of the customers (Crosby, 1979). Subsequently, the emphasis was put on achieving maximum customer satisfaction (Gronroos, 1984). After that, the focus shifted from the end result to the processes that are the key to a good service delivery. However, in this study project quality is referred to as the value government projects add to the quality of life of the citizens.

\section{Project Timeliness}

Rao, Rao, and Muniswamy (2011) define project delivery time as the amount of time taken to respond to the needs and wants of the firm's target users. That is, project timeliness shows the speed at which government projects are made available to the citizens. Delivery time relate to the level of efficiency of making projects available to the user. Project timeliness provides an indication of how successful the government is at providing products and services to the populace. This metric is most important in public sector management as it integrates the measurement of performance from the end-users' point of view.

Project delivery time in this work is defined as the speed at which government projects meet the citizen's expectation. It provides an indication of the potentiality of the government in providing products and services to the citizens as at when it is needed. 


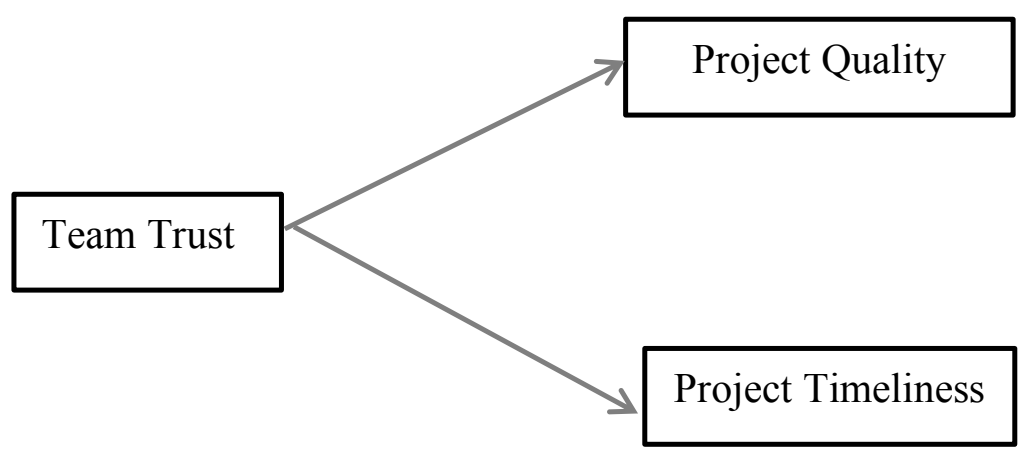

Fig. 1 Operational Framework

\section{Methodology}

The Bayelsa State civil service has 149 parastatals which comprise 34 ministries, 5 commissions and 110 departments and agencies. However, since this study is about team trust and project performance, the target population is made up of project team members. Specifically, the study will focus on project managers, supervisors and engineers in these parastatals. The respondents will be drawn from the Ministries of Works and Infrastructure, Science and Technology and Manpower Development, Mineral Resources, Local Government, Land and Survey, Energy, Water Resources, Housing and Urban Development, Education, Special Projects, Environment and three agencies. These ministries were chosen based on the judgment that they have not less than five teams members which are involved in monitoring and implementing (sometimes through direct labour) government projects. Table 1 below indicates the number of team members in each of the ministries:

Table 1: Ministries under consideration

\begin{tabular}{|c|c|c|}
\hline $\mathbf{S} / \mathbf{N}$ & Ministries & No. of Team Members \\
\hline 1. & Works and Infrastructure & 13 \\
\hline 2. & Education & 9 \\
\hline 3. & Special projects & 10 \\
\hline 4. & Land and Survey & 6 \\
\hline 5. & Energy & 6 \\
\hline 6. & Water Resources & 12 \\
\hline 7. & Mineral Resources & 9 \\
\hline 8. & Science and Technology and Manpower & 6 \\
\hline 9. & Development & 8 \\
\hline 10. & Lousing and Urban Development & 12 \\
\hline 11. & Environment & 13 \\
\hline 12. & Bayelsa State Housing and Property Development & 14 \\
\hline 13. & Authority & 5 \\
\hline 14. & Bayelsa State Capital City Development Authority & 131 \\
\hline 15. & Total Senior Secondary School Board & \\
\hline
\end{tabular}




\section{Data Analysis Techniques}

Several statistical techniques were used to analyse data in this study. First, the demographic details of the respondents were analysed using pie charts and percentages. Secondly, univariate analyse was carried out by examining the individual characteristics of the variables via mean, standard deviation and kurtosis.

Lastly, to the test the study hypotheses, Spearman's Rank Order Correlation coefficient was deployed. The choice of the Spearman's rho is informed by its suitability to the type of data (ordinal data) which were collected (Saunders, Lewis \& Thornhill, 2012). Also, they are suitable since the aim of the study is to examine the relationships between the dimensions and measures of these constructs (Salkind, 2007; Pallant, 2013).

In sum, the choices of Spearman's Rank order Correlation Coefficient and Kendall's tau correlation coefficient were based on fact that:

I. The study is concern on the relationship between two variables.

II. The data is ordinal in nature.

\section{Decision Rules}

In testing hypotheses, the following decision rules will apply:

Step one

The null hypothesis is to be accepted if the p-value is less than or equal to 0.05 , otherwise it will be rejected.

Step two

In interpreting the correlation values, the criteria by Gravetter and Walnau (2013) will apply:

$0=$ No relationship

$0.1-0.29=$ Weak relationship

$0.3-0.69=$ Moderate relationship

$0.7-0.99=$ Strong relationship

$1 \quad=$ Perfect relationship

The hypotheses will be tested at 5\% level of significance. 
Data Analyses and Findings

Table 2: Correlation Matrix of Study Constructs

\begin{tabular}{|c|c|c|c|c|c|c|}
\hline & & & $\begin{array}{c}\text { Team } \\
\text { Integrity }\end{array}$ & $\begin{array}{l}\text { Project } \\
\text { Quality }\end{array}$ & $\begin{array}{c}\text { Project } \\
\text { Timeliness }\end{array}$ & $\begin{array}{c}\text { Project } \\
\text { Satisfaction }\end{array}$ \\
\hline \multirow{12}{*}{$\begin{array}{l}\text { Spearman's } \\
\text { rho }\end{array}$} & \multirow{4}{*}{ Project Integrity } & Correlation & 1.000 & $.506^{\star \star}$ & $.574^{* *}$ & $.685^{* *}$ \\
\hline & & $\begin{array}{l}\text { Sig. (2- } \\
\text { tailed) }\end{array}$ & & .000 & .012 & .009 \\
\hline & & $\mathrm{N}$ & 112 & 112 & 112 & 112 \\
\hline & & $\begin{array}{l}\text { Correlation } \\
\text { Coefficient }\end{array}$ & .506 & 1.000 & .189 & .263 \\
\hline & \multirow[t]{3}{*}{ Project Quality } & $\begin{array}{l}\text { Sig. (2- } \\
\text { tailed) }\end{array}$ & .000 & . & .084 & .016 \\
\hline & & $\mathrm{N}$ & 112 & 112 & 112 & 112 \\
\hline & & $\begin{array}{l}\text { Correlation } \\
\text { Coefficient }\end{array}$ & .574 & .189 & 1.000 & $.381^{* *}$ \\
\hline & \multirow[t]{2}{*}{ Project Timeliness } & $\begin{array}{l}\text { Sig. (2- } \\
\text { tailed) }\end{array}$ & .012 & .084 & & .000 \\
\hline & & $\mathrm{N}$ & 112 & 112 & 112 & 112 \\
\hline & \multirow[t]{3}{*}{ Project Satisfaction } & $\begin{array}{l}\text { Correlation } \\
\text { Coefficient }\end{array}$ & $.685^{\star *}$ & .263 & $.381^{* *}$ & 1.000 \\
\hline & & $\begin{array}{l}\text { Sig. (2- } \\
\text { tailed) }\end{array}$ & .009 & .016 & .000 & \\
\hline & & $\mathrm{N}$ & 112 & 112 & 112 & 112 \\
\hline
\end{tabular}

**. Correlation is significant at the 0.01 level (2-tailed).

*. Correlation is significant at the 0.05 level (2-tailed).

Table 2 above illustrates the association between team trust and the measures of project performance. The results reveal that team trust has moderate but positive and significant relationships between all the measures of project performance. Specifically, team trust and product quality ( $\mathrm{rho}=.574, \mathrm{n}=112$ and $\mathrm{P}<0.05$ ), team trust and project timeliness (rho $=$ $.574, \mathrm{n}=112$ and $\mathrm{P}<0.05)$. Based on the results, the null hypotheses were rejected and their alternatives accepted which are stated as follows:

i. There is significant relationship between team trust and project quality.

ii. There is significant relationship between team trust and project timeliness.

\section{Discussion of Findings}

Hypotheses 1 and 2 examined the associations between team trust, project quality and project timeliness. The results show that team trust has positive and significant relationships with all the measures. This implies that, the more team members show integrity the higher the performance of the team in terms of delivering quality project as and when due. This finding is in consonant with the submission of Jiang, Zhao and Zuo (2017), who studied effects of distrust and trust on project success among Chinese construction firms and discovered that the presence of trust ensure project success, therefore recommending that project managers should frequently evaluate level of trust and implement appropriate control strategy when distrust is seen.

Likewise, Erdem, Ozen and Atsan (2003) examined the nexus between trust and team performance in Turkey. They found that trust is a necessary underpinning factor in team performance. Hence, recommended that managers should build trust among team members and make it a key component of management agenda. Contrarily, Preast (2012) investigated 
the development of "team trust over time and its effect on performance when using Michaelsen's team-based learning" among veterinary medical students in the USA and found that other factors may have influence academic performance of the students rather than trust.

\section{Recommendations}

Based on the results and findings obtained from the analyses of data, the following recommendations were put forward to help improve project performance, especially as it pertains to project quality, timeliness and satisfaction:

i. Team members should be supportive to their colleagues. This action will increase benevolence and trust among members and ensures that projects delivered conform to specification. Also, individual members should show interest in the wellbeing of other members so as encourage one another. This will inspire members to put in their best and deliver projects of high quality. Likewise, team members should make effort to protect each other in times of difficulty, by so doing team objectives for each project will be achieved.

ii. ii. Ethical codes should be developed for team members. This will boost trust and leads to timely completion of projects. In addition, team members should endeavour to keep to their promises since this will build trust and inspire high project performance. Also, truthfulness and honesty should be the watchword of every team member. This will enhance trust among members and ensure on-time delivery of projects.

iii. iii. Teams should be made up of competent individuals who can be trusted. This will help achieve project satisfaction. Furthermore, members should solve problems together in order to build trust and unity. This will help reduce individual member's stress and deliver satisfactory projects to the end-users. Additionally, adequate be carried out at every stage of the project development so as to $\mathrm{d}$ projects to the beneficiaries.

\section{Research Limitation and Future Direction}

The main limitation in this work is the fact that the study was restricted to civil services in Bayelsa State. This could affect the generalization of the research findings to other sectors of the economy. Another limitation is the fact that the research instrument adopted was developed in the advanced country which did not really considered the peculiarity of the Nigerian economy. However, validity and reliability of the instrument was carried out to overcome this limitation. Drawing from the limitation, future researches should investigate how team trust relates with project timeliness and quality in other sector of the economy. Again, a longitudinal survey design should be adopted by future researchers in their study as such may give a more valid result compared to the cross-sectional survey. 


\section{Conclusion}

General, this paper empirically determined how team trust impacts on project quality and timeliness in Bayelsa state civil service. The survey design was adopted and the retrieved data was analysed using Spearman's Rank Order Correlation coefficient. Team trust does significantly impact on project quality and project timeliness. The existence of trust among team members help enhance brainstorming which could positively increase the level of project performance as it relates with quality and timeliness. An increase in team trust leads to a corresponding increase in quality project delivered by the civil service $n$ Bayelsa. This by extension implies that team trust enables the employees to display their ingenuity in the process of project execution which thus result in timely delivering of project and in superior quality of that project. Conclusively, a consigned effort to enhance team trust is necessary in boosting timeliness and quality of projects.

\section{References}

Abiodun, O. E., Segbenu, N. S., Oluseye, O. (2017). Factors Affecting Contractors' Performance in Construction Project Delivery in Akure, Ondo State, Nigeria. Journal of Knowledge Management, Economics and Information Technology, 7(4), 1-23.

Adams, B. D., Waldherr, S., \& Sartori, J. (2008). Trust in teams scale. Trust in leaders scale. Manual for administration and analyses. Defence Research and Development, Toronto, ON.

Adams, B.D. \& Sartori, J. (2006). Validating the trust in teams and trust in leaders scales. Defence Research and Development, Toronto, ON.

Adams, B.D., Lora E., Bruyn, L.E., \& Greg C. G. (2004). Creating a measure of trust in small military teams. Defence Research and Development, Toronto, ON.

Agle, B. R., Donaldson, T., Freeman, R. E., Jensen, M. C., Mitchell, R. K., \& Wood, D. J. (2008). Toward superior stakeholder theory. Business Ethics Quarterly, 18(2), 153190.

Ahmed, R. \& Anantatmula, V. S. (2017). Empirical study of project managers leadership competence and project performance. Engineering Management Journal, 27(1), 118.

Akanni, P.O., Oke, A. E. \&Akpomiemie, A. O. (2015). Impact of environmental factors on building project performance in Delta State, Nigeria. Housing and Building National Research Center Journal, 11,71-77.

Ali, H. A. E. M., Al-Sulaihi, A. I., Al-Gahtani, K. S. (2013). Indicators for measuring performance of building construction companies in Kingdom of Saudi Arabia. Journal of King Saud University - Engineering Sciences, 25, 125-134

Alijanpour, M., Dousti, M. \& Alijanpour, M. (2013). The Relationship between organizational commitment and organizational trust of staff. Annals of Applied Sport Science, 1(4), 45- 52.

Allen, D. G., Shore, L. M., \& Griffeth, R. W. (2003). The role of perceived organizational support and supportive human resource practices in the turnover process. Journal of Management, 29(12), 99-118.

Amade, E. C., Ubani, U. F. A., \& Okorocha, K. A. (2015). Factors for containing failure and abandonment of public sector construction projects in Nigeria. Journal of Building Performance, 6(1), 63-76.

Appelbaum, E., Bailey, T., Berg, P., \& Kalleberg, A. (2000). Manufacturing advantage: Why high-performance work systems payoff Cornell :University Press. 
Ariyabuddhiphongs, V. \& Kahn, S. I. (2017) Transformational leadership and turnover intention: The mediating effects of trust and job performance on cafe employees in Thailand . Jbi/rwa/ of Human Resources in Hospitality and Tourism, 16:2,215-233.

Aryee, S. A., Budhwar, P. \&Chen, Z. (2002). Trust as a mediator of the relationship between organizational justice and organizational outcomes: Test of a social exchange model. Journal of Organizational Behavior, 23(23), 267-85.

Ba§tug, G., Pala, A., Kumarta§li, M., Gunel, I. \& Duyan, M. (2016). Investigation of the relationship between organizational trust and organizational commitment. Universal Journal of Educational Research, 4(6), 1418-1425.

Bateman, T. S. \& Organ, D. W. (1983). Job satisfaction and the good soldier: The relationship between affect and citizenship. Academy of Management Journal, 26(4), 587-595.

Batholomew, P., \& Sule, O. E. (2017). Appraisal and evaluation of government projects in Rivers Mid Bayelsa States, Nigeria. International Journal of Investment Management and Financial Innovations, 3(6), 71-76.

Berber, N., Slavic, A., \& Aleksic, M. (2020). Relationship between perceived teamwork effectiveness and team performance in banking sector of Serbia. Sustainability, 12, $1-15$.

Bharadwaj, N. \& Matsuno, K. (2006). Investigating the antecedents and outcomes of customer firm transaction cost savings in a supply chain relationship. Journal of

Braun, S., Peus, C., Weisweiler, S. \& Frey, D. (2013). Transformational leadership, job satisfaction, and team performance: A multilevel mediation model of trust. The Leadership Quarterly, 24(1), 270-283.

Costa, A. C., Fulmer, C. A., \& Anderson, N. R. (2017). Trust in work teams: An integrative review, multilevel model, and future directions. Journal of Organizational Behavior, 39(2), 169-184.

Eja, K. M., \& Ramegowda, M. (2020). Government project failure in developing countries: a review with particular reference to Nigeria. Global Journal of Social Sciences, 19, 35-47.

Ellonen, R., Blomqvist, K. \& Puumalainen, K. (2008). The role of trust in organizational Innovativeness. European Journal of Innovation Management, 11(2), 160-181.

Erdem, F. \& Ozen, J. (2003). Cognitive and affective dimensions of trust in developing team Performance. Team Performance Management: An International Journal, 9(5/6), 131- 135.

Erdem, F., Ozen, J., \& Atsan, N. (2003). The relationship between trust and team performance. Work Study, 52(7), 337-340.

Esty, B. (2003). The economic motivations for using project finance. Boston: Harvard Business Schoolpublishing.

Esty, B. (2004). Modern project finance - A casebook. London: John Wiley \& Sons, Inc.

Esty, B., \& Megginson, W. (2003). Creditor rights, enforcement, and debt ownership structure: Evidence from the global syndicated loan market. Journal of Financial and Quantitative Analysis, 38, 37-59.

Esty, B., \& Sesia, A. (2007). An overview of project finance \& infrastructure finance - 2006 update. Boston: Harvard Business School publishing.

Etikan, I., Musa, S. A., \& Alkassim, R. S. (2016). Comparison of convenience sampling and purposive sampling. American Journal of Theoretical and Applied Statistics, 5(1), 14 
Fabozzi, F., Davis, H., \&Choudhry, M. (2006). Introduction to structured finance. London: Wiley Finance.

Falk, A. \&Fischbacher, U. (2000).A theory of reciprocity. Institute for Empirical Research in Economics, University of Zurich, Working Paper No. 6.

Feitosa, J., Grossman, R., Kramer, W. S., \& Salas, E. (2020). Measuring team trust. A critical and meta-analytical review. Journal of Organizational Behaviour, 41(5), 479-501.

Foley, C., \&Greenwood, R. (2010). The evolution of corporate ownership after IPO: The impact of investorprotection. The Review of Financial Studies, 23,1231-1260.

Freeman, R. E. (1984). Strategic management: A stakeholder approach. Boston: Pitman Publishing.

Freeman, R. E. (2005). Stakeholder theory. In P. H. Werhane \& R. E. Freeman (Eds.), The Blackwell encyclopedia of management: Business ethics. Oxford: Blackwell Publishing.

Fung, H. P. \& Siow, H. L. (2013). Relationship between team satisfaction and project performance as perceived by project managers in Malaysia - A mixed methods study. Open Journal of Social Science Research, 1(9), 238-249.

Gallegos, F., Senft, S., Manson, D. P., \& Gonzales, C. (2004). Information technology control and audit ( $2 \mathrm{n}$ ed.). Boca Raton, FL: Auerbach.

Gambetta, D. (1988). Trust making and breaking cooperative relations. New York: Basil Blackwell.

Gatti, S. (2008). Project finance in theory and practice - Designing, structuring, and financing privateand public projects. Academic Press Advanced Finance Series, 2(4), 45-67.

Gatti, S., Kleimeier, S., Megginson, W., \& Steffanoni, A. (2013). Arranger certification in project finance. Financial Management, 42,1-40.

Gibbons, D. E. (2004). Friendship and advice networks in the context of changing professional values.Administrative Science Quarterly, 49(2), 238-59.

Hughes, S. W., Tippett, D. D., \& Thomas, W. K. (2004). Measuring project success in the construction industry. Engineering Management Journal, 16(3), 31-37.

Imam, H., \& Zaheer, M. K. (2021). Shared leadership and project success: the roles of knowledge sharing, cohesion and trust in the team. International Journal of Project Management, 30(40), 1-11.

Imenda, S. (2014). Is There a conceptual difference between theoretical and conceptual frameworks? Journal of Social Science, 38(2), 185-195.

Inkpen, A.C., \& Currall, S.C. (1997). International joint venture trust: An empirical examination.

In P.W. Beamish \& J.P. Killing (Eds.), Cooperative strategies: Vol. I. North American perspectives (pp. 308-334). San Francisco: New Lexington Press.

Isoni, A. \& Sugden, R. (2018). Reciprocity and the paradox of trust in psychological game theory. Journal of Economic Behavior and Organization, 10(28), 1-9.

Jaakson, K., Reino, A., McClenaghan, P. B. (2018). The space between - linking trust with individual and team performance in virtual teams. Team Performance Management: An International Journal, 25(1/2), 30-46.

Peter, B., \& Eniola, S. O. (2017). Appraisal and evaluation of government projects inRivers and Bayelsa States, Nigeria International Journal of Investment Management and Financial Innovations, 3(6), 71-76.

Phillips, R., Freeman, R. E. \& Wicks, A. C. (2003). What stakeholder theory is not. Business Ethics Quarterly, 13(4), 479-502. 
Pinto, J. K. (2007). Project management: Achieving competitive advantage. New Jersey: Pearson Education, Inc.

Pinto, J. K., \& Slevin, D. P. (1986). The project implementation profile: New tool for project managers. Project Management Journal, 17(4), 57-69.

Pinto, J. M. (2017). What is project finance?. Investment Management and Financial Innovations, 14(1-1), 200-210.

Preast, V. (2012). The development of team trust over time and its effect on performance when using Michaelseris team-based learning. An unpublished Ph.D Thesis submitted to Iowa State University Capstones.

down" among black and non-black employees. Journal of Applied Psychology, 92, 650 665.

Rodriguez-Rivero, R., Ortiz-Marcos, I., Romero, J., \& Ballesteros-Sanchez, L. (2020). Finding the links between risk management and project success: evidence from international development projects in Colombia. Sustainability, 12, 1-19.

Six, F., \& Sorge, A. (2008). Creating a high-trust organization: An exploration into organizational policies that stimulate interpersonal trust building. Journal of Management Studies, 45(5), 857-84.

Sluss, D. M., Klimchak, M., \& Holmes, J. J. (2008).Perceived organizational support as a mediator between relational exchange and organizational identiflcation.Jowr ${ }^{\wedge} /$ of Vocational Behavior, 73,457-464.

Smith, J.B., \& Barclay, W.B. (1997). The effects of organizational differences and trust on the effectiveness of selling partner relationships. Journal of Marketing, 61, 3-21.

Snape, E, \& Redman, T. (2010). HRM practices, organizational citizenship behaviour, and performance: A multi-level analysis. Journal of Management Studies, 47(7), 12191247.

Stahl, G. K., \& Sitkin, S. B. (2004). Trust in mergers and acquisitions. In G. K. Stahl and M. Meddenhall (Eds.), Mergers and acquisitions: Managing culture and human resources. MA, USA: Stanford University Press.

Standish Group International (2009). CHAOS summary report 2009. The Standish Group International, Inc.

Sztompka, P. (1999). Trust: A sociological theory. Cambridge: Cambridge University Press.

Taillieu, T. (1990, May). The impact of an integrated information network in a Belgian supermarket chain. Paper presented at the international conference on Computer, Man and Organization, Nivelles, Belgium.

Tamene, E. H. (2016). Theorizing conceptual framework. Asian Journal of Educational Research, 4(2), 50-56.

Thamhain, H. J. (2004). Linkages of project environment to performance: Lessons for team leadership. International Journal of Project Management, $22(20)$, 533-544.

Thomas, E.U., \& Martin, L. (2004). Essentials of construction project management. Australia: University of New South Wales Press Ltd.

Triana, M.D.C., Richard, O.C., \& Yiicel, I. (2017). Status incongruence and supervisor gender asmoderators of the transformational leadership to subordinate affective organizational commitment relationship. Personnel Psychology, 70(2), 429-467.

Tseng, H. and Ku, H.-Y. (2011). The relationships between trust, performance, satisfaction, and development progressions among virtual teams. The Quarterly Review of Distance Education, 12(2), 81-94.

Vadali N., Tiwari, A. P., \& Rajan A., T. (2014). Effect of the political environment on public private partnership projects. Journal of Infrastructure Development, 6(2), 145-165. 
Van der Heijden, B. (2001). Age and assessments of professional expertise: the relationship betweenhigher level employees' age and self-assessments or supervisor ratings of professional expertise. International Journal of Selection and Assessment, 9(4), 309324.

Van Dijk, H., van Engen, M.L. \& van Knippenberg, D. (2012). Defying conventional wisdom: a metaanalyticalexamination of the differences between demographic and job-related diversityrelationships with performance. Organizational Behavior and Human Decision Processes, 119(1), 38-53.

Van Dyne, L., Vandewalle, D., Kostova, T., Latham, M. E. \&Cummings, L. L. (2000). Collectivism, propensity to trust and self-esteem as predictors of organizational citizenship in a non-work setting. Journal of Organizational Behavior, 21(1), 3-23.

Van Knippenberg, D., \& Schippers, M.C. (2007). Work group diversity. Annual Review of Psychology, 58(1), 515-541.

Wu, X., Zhao, W., and Ma, T. (2019). improving the impact of green construction management on the quality of highway engineering projects. Sustainability, 11,18951918.

Zalabak, P. S., \&Winograd, E. K. G. (2000). Organizational trust: What it means, why it matters. Organization Developmental Journal, 18(4), 35-49.

Zand, D. E. (1972).Trust and managerial problem solving. Administrative Science Quarterly, 17(2), 229-39.

Zand, D. E. (1991).The leadership triad, knowledge, trust and power. New York: Oxford University Press.

Zhang, A. Y., Tsui, A. S., Song, L. J., Chaoping, L. \& Jia, L. (2008). How do I trust thee? The employee-organization relationship: Supervisory support and middle manager trust in the organization. Human Resource Management, 47(1), 111-32. 